\title{
Phnom Penh's Municipal drinking water supply: water quality assessment
}

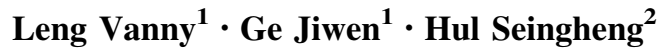

Received: 24 March 2015/Accepted: 21 April 2015/Published online: 5 May 2015

(C) Springer International Publishing 2015

\begin{abstract}
The quality of the municipal drinking water supply for the residents of Phnom Penh, Cambodia is assessed. Based on measurements of water quality for the source water, the treated water and the tap water taken over a 3-year period between 2009 and 2011, the evidence is that the water quality is good and meets both World Health Organization and national drinking water standards. This is despite only basic processes being employed in the water treatment process. This is possible because the source water is of good quality. However, developments in the Mekong river basin pose a number of threats to the quality of the source water. Source water quality degradation in terms of nutrients, heavy metals and pesticides is likely to impact the drinking water quality as the water treatment processes available do not address these species.
\end{abstract}

Keywords Drinking water $\cdot$ Phnom Penh $\cdot$ Water quality $\cdot$ Assessment $\cdot$ Water treatment $\cdot$ Pollution

Electronic supplementary material The online version of this article (doi:10.1007/s40899-015-0004-9) contains supplementary material, which is available to authorized users.

Leng Vanny

lengvanny@yahoo.com

Ge Jiwen

gejiwen2002@aliyun.com

Hul Seingheng

hul@itc.edu.kh

1 School of Environmental Study, China University of Geosciences (CGU), Wuhan 430074, China

2 Institute of Technology of Cambodia (ITC), Phnom Penh, Cambodia

\section{Introduction}

Access to safe and clean water is a basic need. The use of unsafe water and improper disposal of human waste, in combination with low hygiene awareness, can result in sickness that prevents people from working and being productive, thus contributing to increased levels of poverty. However, many local authorities in developing countries are unable to provide safe drinking water for some of their population. More than 1.1 billion people in the world, or $15 \%$ of the global population, lack access to safe water (Sobsey 2006).

A particular challenge extant in many regions of the world is establishing clean safe drinking water for urban populations following an extended period of war or conflict. This is a particular problem in poorer nations where corruption and lawlessness can complicate the establishment and delivery of a reliable drinking water source. Following, the Khmer Rouge genocide, foreign occupation and years of international isolation the capital city of Cambodia, Phnom Penh in the early 1990s faced such a challenge. This challenge has been met by the Phnom Penh water supply authority (PPWSA) who have in the intervening years been successful in establishing a municipal drinking water supply (Dany et al. 2000). Delivery of supply to a rapidly growing urban population in Phnom Penh and improvements to the water quality have established the PPWSA as an exemplar for other authorities to learn from (Biswas and Tortajada 2010).

In Cambodia, securing a safe water supply for the citizens is important for promoting public health and economic wellbeing. For a number of decades, Phnom Penh City had inadequate water quantity and quality and water-related diseases accounted for nearly $30 \%$ of all hospitalizations (UNICEF 2014a). The national targets in the Cambodian millennium development goals (CMDG's) for improving 
access to safe water are different for the urban and rural populations. These goals state that by 2015 , the proportion of the population with access to a safe water source will be $50 \%$ in rural areas and $80 \%$ in urban areas: or $58 \%$ as a nationwide average (Thailand MMoNRaEo 2006). Cambodia has already met these targets (UNICEF 2014b), and improvements to the provision of safe water in Phnom Penh have played a significant role in this achievement. The impact that improving access to safe water supply services has had on the health of Cambodians is indicated by the reduction in infant (under five) mortality rate from 115 per 1000 live births to 22 per 1000 live births between 1990 and 2012 (UNICEF 2014a), and this has been accompanied by an increase in access to safe drinking water from $34 \%$ (UNICEF 2006) to $67 \%$ (UNICEF 2014b) of the population over the period from 2002 to 2014.

In terms of the water distribution system, unaccounted for water routinely exceeded $80 \%$ during the late 1980s, and the pressure of water was so low that most households received no supply, even though they were connected to the system. However, since then significant improvements have been implemented (Biswas and Tortajada 2010). During the 15-year timeframe between 1993 and 2009, the annual water production increased by over $400 \%$, the distribution network by over $500 \%$, water pressure in the system by a factor of 12 , and the customer base by a factor of six. Unaccounted for water reduced from 72 to $6 \%$ (Biswas and Tortajada 2010). Table 1 summarises the state of the water supply in 1993 and 2009 and illustrates the substantial improvement the citizens of Phnom Penh have experienced in regard to access to water. Cambodia had no water quality standard for drinking water until the late 1990s when the PPWSA changed the parameters being monitored and adopted water quality standards from the World Health Organization (WHO).

The successes of the PPWSA in establishing an effective water supply to a rapidly growing city in a poor country emerging from war and decades of neglect with endemic corruption (Un 2005) are worthy of attention as similar challenges are faced in many cities where stability has emerged and infrastructure for growth and development is being implemented.

Table 1 Phnom Penh's expanding water supply (PPWSA 2014)

\begin{tabular}{lll}
\hline 1993 & Indicators & 2009 \\
\hline $65,000 \mathrm{~m}^{3} /$ day & Production capacity & $300,000 \mathrm{~m}^{3} /$ day \\
$\mathrm{NA}^{*}$ & Water quality & $\mathrm{WHO}$ \\
$20 \%$ & Coverage area & $90 \%$ \\
$10 \mathrm{~h} /$ day & Supply duration & $24 \mathrm{~h} /$ day \\
$0.2 \mathrm{bar}$ & Supply pressure & $2.5 \mathrm{bar}$ \\
26,881 & Number of connections & 191,092 \\
\hline
\end{tabular}

This paper reports on the water quality of the source water, the treated water and the tap water for the municipal water supply of Phnom Penh, the capital city of Cambodia. Relationships are investigated between the water quality of the source water and the water quality of the municipal supply with a view to understanding how the system may be improved, to anticipate challenges to future water quality.

\section{Materials and methods}

Currently, Phnom Penh has three water treatment plants (WTP) and each draws its water from a different source. The Phum Prek WTP supply is taken from the Tonle Sap near Phnom Penh Port. The Chamkar Mon WTP supply uses the pump station located near the Thai Embassy along the Tonle Bassac, and Chrouy Changva WTP pump station is located along the Mekong river. The locations are shown in Fig. 1. The combined capacity of the three plants at $330,000 \mathrm{~m}^{3} /$ day is sufficient to meet the current needs of the city, but only just. New facilities are shortly to come online and these will need to be expanded regularly over the coming decades to address the increasing population and consequent demand for water.

In order to assure the quality of the water supply, it is necessary to monitor a wide range of water quality parameters on a regular basis at each WTP. Water quality monitoring is carried out using physical, chemical and biological tests, on a regular basis by the PPWSA. For source water, 36 parameters are measured, 38 parameters are measured for treated water and a further eight parameters are measured for tap water from a number of sites around Phnom Penh. PPWSA monitors water quality at three different intervals. Routine tests are conducted at treatment plants every day for all the parameters, except the heavy metals; weekly tests are made on selected samples from the distribution system (i.e. tap water); and a general test of all parameters is conducted monthly. Water quality parameters are measured following ISO standard protocols. Water quality testing enables the treated water to be compared to the WHO guidelines (WHO 2004) and the Cambodian National Drinking Water Quality Standard (CNDWQS) to ascertain the water quality. Notably, many contaminants are not monitored including pesticides and some heavy metals, which are not included in the CNDWQS standard.

\section{Results}

\section{Quality of the source water}

Water is sourced from different locations for each of the water treatment plants, and the water quality at each 
Fig. 1 Locations of the three water treatment plants (WTP) investigated in this work. They are located in Phnom Penh Cambodia. The markers show the locations of the Chrouy Changva $\left(11^{\circ} 35^{\prime} 13^{\prime \prime} \mathrm{N}\right.$, $\left.104^{\circ} 56^{\prime} 15^{\prime \prime} \mathrm{E}\right)$, Phum Prek $\left(11^{\circ} 32^{\prime} 16^{\prime \prime} \mathrm{N}, 104^{\circ} 55^{\prime} 14^{\prime \prime} \mathrm{E}\right)$ and Chamkar Mon $\left(11^{\circ} 34^{\prime} 26^{\prime \prime} \mathrm{N}\right.$, $\left.104^{\circ} 54^{\prime} 59^{\prime \prime} \mathrm{E}\right)$ water treatment plants

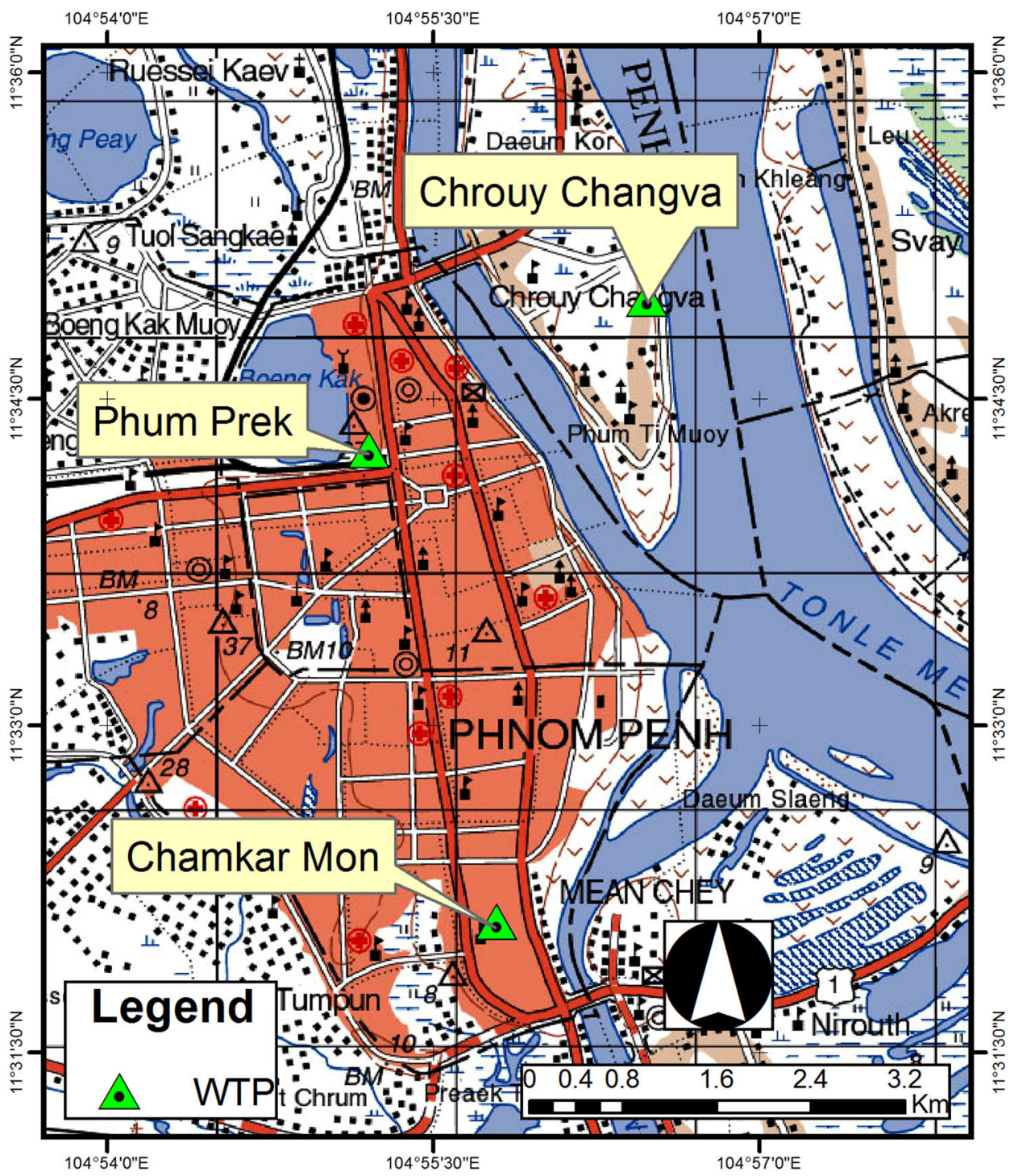

location is measured. These data are summarised in Table 2. These parameters are grouped into physical, chemical and biological tests. Note, that physical tests primarily reflect the public perception of the water quality, whereas chemical and biological tests measure parameters important for water processing and public health. Note that for the majority of the parameters reported, the standard deviations are large. The implication is that measurements vary considerably and the mean value (which is used in most public reports of water quality) is not, on its own, a robust measure. The implications of this are discussed further below.

Based on physical parameters, the surface water currently used as source water for all of the treatment plants is of good quality and therefore can be readily treated to a standard suitable for drinking water. By weighting various measures of water quality to arrive at a single number, a convenient measure of water quality can be obtained that is often referred to as a water quality index (WQI) (Couillard and Lefebvre 1985). We have calculated the WQI for the source waters using the method of Hallock (2002) and (Mitchell and Stapp 2000), which combines weighted values derived from the important parameters of dissolved oxygen, Faecal coliform, $\mathrm{pH}$, phosphate, nitrate, turbidity and total solids. The WQI for the source water at the Chruoy Changvar, Chamkar Mon and Phum Prek WTP's was found to be 70,67 and 59, respectively. This range is consistent with a water quality label of medium to good water quality. We note that the parameters responsible for reducing the WQI in the source waters for Phnom Penh are the faecal coliform count, turbidity, solids and the nitrate levels. The water treatment processes in place can address the coliform count, turbidity and solids levels but not nitrate levels. The coliform counts are high at Chruoy Changvar and Chamkar Mon and very high at Phum Prek, this is usually taken as an indicator of a 
Table 2 Source Water of PPWSA daily mean and standard deviation of quality measures for the years 2009-2011

\begin{tabular}{|c|c|c|c|c|c|c|c|}
\hline \multirow[t]{2}{*}{ Item } & \multirow[t]{2}{*}{ Unit } & \multicolumn{2}{|c|}{ Phum Prek WTP } & \multicolumn{2}{|c|}{ Chruoy Changvar WTP } & \multicolumn{2}{|c|}{ Chamkar Mon WTP } \\
\hline & & Mean & $\pm \mathrm{STD}$ & Mean & \pm STD & Mean & $\pm \mathrm{STD}$ \\
\hline \multicolumn{8}{|l|}{ Physical test } \\
\hline Temperature & ${ }^{\circ} \mathrm{C}$ & 28.86 & 1.31 & 28.87 & 1.51 & 28.4 & 1.25 \\
\hline $\mathrm{pH}$ & & 7.17 & 0.21 & 7.89 & 0.29 & 7.30 & 0.22 \\
\hline Turbidity & NTU & 115.17 & 62.48 & 112.03 & 109.57 & 142 & 133.51 \\
\hline Conductivity & $\mu \mathrm{S} / \mathrm{cm}$ & 106.43 & 33.42 & 148.97 & 37.62 & 116 & 36.14 \\
\hline SS & $\mathrm{mg} / \mathrm{l}$ & 94.37 & 55.17 & 92.77 & 94.13 & 108 & 101.06 \\
\hline Colour & TCU & 46.30 & 31.58 & 23.45 & 18.26 & 37.31 & 19.16 \\
\hline TDS & $\mathrm{mg} / \mathrm{l}$ & 53.49 & 16.68 & 74.89 & 18.75 & 58 & 17.67 \\
\hline \multicolumn{8}{|l|}{ Chemical test } \\
\hline $\mathrm{Ca}$ hardness & $\mathrm{mg} / \mathrm{l}$ & 25.91 & 10.76 & 43.80 & 10.47 & 30 & 10.95 \\
\hline Total hardness & $\mathrm{mg} / \mathrm{l}$ & 39.40 & 12.56 & 60.74 & 15.10 & 43 & 13.92 \\
\hline Magnesium hardness & $\mathrm{mg} / \mathrm{l}$ & 13.71 & 3.60 & 16.94 & 5.40 & 13.8 & 4.44 \\
\hline Alkalinity & $\mathrm{mg} / \mathrm{l}$ & 36.69 & 10.09 & 58.06 & 13.65 & 39 & 10.15 \\
\hline Organic substance & $\mathrm{mg} / \mathrm{l}$ & 17.90 & 5.94 & 9.14 & 3.99 & 14.39 & 4.79 \\
\hline Dissolved Oxygen & $\mathrm{mg} / \mathrm{l}$ & 5.68 & 0.96 & 7.44 & 0.20 & 7.25 & 0.29 \\
\hline UV, absorption & & 0.25 & 0.14 & 0.12 & 0.08 & 0.203 & 0.08 \\
\hline Aluminum & $\mathrm{mg} / \mathrm{l}$ & 0.00 & 0.01 & 0.03 & 0.05 & 0.006 & 0.01 \\
\hline Ammonia & $\mathrm{mg} / \mathrm{l}$ & 0.45 & 0.39 & 0.13 & 0.11 & 0.206 & 0.20 \\
\hline Ammonium nitrogen & $\mathrm{mg} / \mathrm{l}$ & 0.38 & 0.35 & 0.11 & 0.09 & 0.17 & 0.16 \\
\hline Carbon dioxide & $\mathrm{mg} / \mathrm{l}$ & 14.39 & 11.88 & 5.51 & 3.70 & 8 & 4.93 \\
\hline Copper & $\mathrm{mg} / \mathrm{l}$ & 0.02 & 0.02 & 0.02 & 0.02 & 0.02 & 0.02 \\
\hline Chloride & $\mathrm{mg} / \mathrm{l}$ & 17.09 & 5.09 & 17.87 & 7.13 & 16.8 & 5.26 \\
\hline Cyanide & $\mathrm{mg} / \mathrm{l}$ & 0.00 & 0.00 & 0.00 & 0.00 & 0.001 & 0.00 \\
\hline Chromium total & $\mathrm{mg} / \mathrm{l}$ & 0.01 & 0.01 & 0.01 & 0.01 & 0.01 & 0.01 \\
\hline Chromium hexa & $\mathrm{mg} / \mathrm{l}$ & 0.01 & 0.01 & 0.01 & 0.01 & 0.01 & 0.01 \\
\hline Fluoride & $\mathrm{mg} / \mathrm{l}$ & 0.13 & 0.13 & 0.14 & 0.08 & 0.12 & 0.08 \\
\hline Iron & $\mathrm{mg} / \mathrm{l}$ & 0.45 & 0.69 & 0.13 & 0.16 & 0.30 & 0.26 \\
\hline Manganese & $\mathrm{mg} / \mathrm{l}$ & 0.02 & 0.01 & 0.02 & 0.04 & 0.019 & 0.02 \\
\hline Nitrate nitrogen & $\mathrm{mg} / \mathrm{l}$ & 1.61 & 1.24 & 1.21 & 0.36 & 1.26 & 0.39 \\
\hline Nitrate & $\mathrm{mg} / \mathrm{l}$ & 6.363 & 2.708 & 5.33 & 1.57 & 5.55 & 1.71 \\
\hline Nitrite nitrogen & $\mathrm{mg} / \mathrm{l}$ & 0.010 & 0.012 & 0.01 & 0.01 & 0.009 & 0.01 \\
\hline Nitrite & $\mathrm{mg} / \mathrm{l}$ & 0.034 & 0.040 & 0.02 & 0.01 & 0.028 & 0.04 \\
\hline Zinc & $\mathrm{mg} / \mathrm{l}$ & 0.05 & 0.04 & 0.06 & 0.03 & 0.04 & 0.03 \\
\hline Phosphate & $\mathrm{mg} / \mathrm{l}$ & 0.15 & 0.12 & 0.08 & 0.06 & 0.13 & 0.11 \\
\hline Sulphide & $\mathrm{mg} / \mathrm{l}$ & 0.010 & 0.008 & 0.01 & 0.01 & 0.009 & 0.01 \\
\hline Sulphate & $\mathrm{mg} / \mathrm{l}$ & 4.8 & 5.5 & 11.35 & 6.15 & 6.3 & 6.20 \\
\hline \multicolumn{8}{|l|}{ Biological test } \\
\hline Total coliform & $\mathrm{cfu} / 100 \mathrm{ml}$ & 17,010 & 21,676 & 3251.20 & 2772.95 & 4776 & 8832.88 \\
\hline Faecal coliform & $\mathrm{cfu} / 100 \mathrm{ml}$ & 3993 & 5186 & 408.89 & 290.33 & 422 & 446.63 \\
\hline
\end{tabular}

high level of pathogens, including viruses. These pathogens and viruses are unlikely to be removed by the water treatment processes employed in Phnom Penh. The very high levels of coliform counts at Phum Prek are likely influenced by local sewerage discharge (Dany et al. 2000).

\section{Water quality following treatment}

The treatment processes employed at the three WTP's in Phnom Penh follow the same well-established methods of using chlorine to disinfect the water, aluminum ions to 
promote flocculation and sedimentation to reduce the turbidity before filtration.

The treatment steps employed are addition of chlorine gas $\left(\mathrm{Cl}_{2(\mathrm{~g})}\right)$ and aluminum sulphate $\left(\mathrm{Al}_{2}\left(\mathrm{SO}_{4}\right)_{3} \bullet 14 \mathrm{H}_{2} \mathrm{O}\right)$ to the source water with strong agitation followed by gentle agitation and coagulation of suspended solids. Subsequently, the water is gently agitated during flocculation of the coagulant and sedimentation of flocs. The water is then filtered through sand before further addition of chlorine gas $\left(\mathrm{Cl}_{2(\mathrm{~g})}\right)$ for residual disinfection. At this stage, the water is analysed and then stored for distribution.

The main goal of treatment is to disinfect the water and remove suspended materials. Note that more advanced water treatment processes designed to remove heavy metals, nutrients and particular organic pollutants (such as adsorption, ion exchange and reverse osmosis, charcoal filtering or biological remediation) are not employed in Phnom Penh. Therefore, many of these species will not be influenced by the water treatment. Additionally, it should be noted that the use of chlorine gas and the addition of aluminum sulphate should result in increased levels of $\mathrm{Al}^{3+}, \mathrm{Cl}^{-}$and $\mathrm{SO}_{4}{ }^{2-}$ ions in the treated water compared to the source water. In Table 3, the mean and standard deviation is reported for a range of physical, chemical and biological measures of treated water quality and compared to the CNDWQS and WHO drinking water standards. Note that the standard deviation for many measures is a significant percentage of the measured value. This reflects a large variation in the measured parameters and therefore suggests that the mean value alone is not a sufficient measure for judging the water quality. This will be discussed further later. With this caveat in mind, the presented parameters indicate that the Phnom Penh treated water meets both CNDWQS (Cambodia MoimaeKo 2004; PPWSA 2014) and WHO (2004) drinking water standards. Following treatment, the WQI index (Hallock 2002; Mitchell and Stapp 2000) for the treated water at the Chruoy Changvar, Chamkar Mon and Phum Prek WTP's was calculated to be 91,88 and 87 , respectively. This range is consistent with a water quality label of excellent and indicates that the water treatment process is effective in mitigating the levels of faecal coliform, turbidity and solids that reduced the WQI index in the source water. The nitrate levels remain in the medium range.

\section{Time series data}

The source water will undergo variations in quality both due to seasonal effects and other factors. This is evidenced when the water quality parameters are presented as a time series. The turbidity of the source water at the 3 WTP's is shown as a time series in Fig. 2. The periodic turbidity increases reflect the annual monsoonal floods that run from
June to December. Statistical analysis of the turbidity of the source water at the Chruoy Changvar WTP shows that is it correlated $(p<0.001)$ with the rainfall measured at Prek Kdam, $30 \mathrm{~km}$ north of Phnom Penh. The seasonal changes in turbidity at the Phum Prek WTP are not as evident as the other WTP's because the source water for the Phum Prek WTP is the Tonle Sap and this river has a complex flow pattern which reverses in direction during the annual flooding. Note these patterns are not reflected in the treated water where the turbidity is greatly reduced (see Online Resource 1, Fig. 1). The turbidity is due to the presence of suspended solids. Dissolved solids show a different seasonal pattern, whereby the concentration of dissolved solids drops during the floods, and the values obtained for the source water and the treated water are nearly equivalent (see Online Resource 1, Fig. 2). Measures of Nitrate, Phosphate and $\mathrm{pH}$ show no significant patterns in the time series data (see Online Resource 1, Figs. 3, 4, 5). For the most important measures of water quality, the mean and standard deviations have been calculated on an annual basis. They show no significant year to year changes (see Online Resource 1, Tables 1, 2).

The measured faecal coliform counts for the source water are shown in Fig. 3 and show that the source water for the Phum Prek WTP has periods of high faecal coliform counts. These periods do not correlate with any obvious properties of the season or the river level and are more likely due to contamination from the nearby sewerage treatment plant (Dany et al. 2000). However, they are reflected in levels of dissolved oxygen levels significantly lower than usual, as evidenced in Fig. 4. Presumably, this is due to a high biological oxygen demand in the contaminated waters.

\section{Tap water quality}

After treatment, the water is stored and then distributed to consumers through a network of pipes. The quality of water delivered to the consumer is therefore dependent on the integrity of the distribution system. As is normal practice, the addition of residual disinfectant (see stage 6 above) is designed to protect any challenges to the water quality that may be encountered during this process. As the added chlorine will slowly react to form gaseous $\mathrm{Cl}_{2}$ and other molecules, the chlorine levels at the tap will be reduced from that measured at the treatment plant. Table 4 summarises the parameters regularly measured to assess tap water quality. Of these the coliform counts and residual chlorine levels are measures important to consumer health, whereas the other measures are primarily related to consumer satisfaction. As expected, the chlorine levels are lower than those measured at the treatment plant. Note that on exceptional occasions, the distribution network has failed and the coliform count is significant at the tap. 
Table 3 Treated water from the three treatment plants of PPWSA mean and standard deviation of quality measures for the years 2009-2011

\begin{tabular}{|c|c|c|c|c|c|c|c|c|c|}
\hline \multirow[t]{2}{*}{ Item } & \multirow[t]{2}{*}{ Unit } & \multicolumn{2}{|l|}{ Standard } & \multicolumn{2}{|c|}{ Chruoy Changvar-WTP } & \multicolumn{2}{|c|}{ Phum Prek-WTP } & \multicolumn{2}{|c|}{ Chamkar Mon-WTP } \\
\hline & & CNDWQS & WHO (2004) & Mean & \pm STD & Mean & $\pm \mathrm{STD}$ & Mean & $\pm \mathrm{STD}$ \\
\hline \multicolumn{10}{|l|}{ Physical test } \\
\hline Temperature & ${ }^{\circ} \mathrm{C}$ & & & 28.6 & 1.5 & 28.6 & 1.3 & 28.3 & 1.3 \\
\hline $\mathrm{pH}$ & & $6.5-8.5$ & $6.5-8.5$ & 7.5 & 0.3 & 6.9 & 0.2 & 6.9 & 0.2 \\
\hline Turbidity & NTU & 5 & 5 & 0.8 & 0.2 & 0.9 & 0.4 & 1.8 & 0.5 \\
\hline Conductivity & $\mu \mathrm{S} / \mathrm{cm}$ & & 400 & 153 & 36 & 122 & 31 & 124 & 35 \\
\hline Colour & TCU & 5 & 15 & 1.7 & 0.8 & 3.0 & 1.3 & 3.9 & 1.7 \\
\hline SS & $\mathrm{mg} / \mathrm{l}$ & & 1 & 0.1 & 0.1 & 0.3 & 0.3 & 0.6 & 0.4 \\
\hline TDS & $\mathrm{mg} / \mathrm{l}$ & 800 & 1000 & 77 & 18 & 61 & 16 & 63 & 17 \\
\hline \multicolumn{10}{|l|}{ Chemical test } \\
\hline Ca hardness & $\mathrm{mg} / \mathrm{l}$ & & 70 & 43 & 10 & 31 & 11 & 30 & 11 \\
\hline Total hardness & $\mathrm{mg} / \mathrm{l}$ & 300 & 100 & 60 & 15 & 45 & 13 & 43 & 13 \\
\hline Magnesium hardness & $\mathrm{mg} / \mathrm{l}$ & & 30 & 17 & 6 & 14 & 4 & 14 & 4 \\
\hline Alkalinity & $\mathrm{mg} / \mathrm{l}$ & & 350 & 50 & 15 & 29 & 10 & 31 & 10 \\
\hline Organic substance & $\mathrm{mg} / \mathrm{l}$ & & & 2.79 & 0.82 & 4.88 & 2.42 & 4.35 & 2.19 \\
\hline Dissolved oxygen & $\mathrm{mg} / \mathrm{l}$ & & & 7.56 & 0.21 & 7.01 & 0.38 & 7.47 & 0.24 \\
\hline UV, absorption & & & & 0.024 & 0.006 & 0.048 & 0.020 & 0.044 & 0.018 \\
\hline Aluminum & $\mathrm{mg} / \mathrm{l}$ & 0.2 & $0.05-0.2$ & 0.08 & 0.08 & 0.02 & 0.03 & 0.03 & 0.02 \\
\hline Ammonia & $\mathrm{mg} / \mathrm{l}$ & 1.5 & & 0.03 & 0.03 & 0.03 & 0.05 & 0.04 & 0.04 \\
\hline Ammonia nitrogen & $\mathrm{mg} / \mathrm{l}$ & & $0.05-0.5$ & 0.03 & 0.03 & 0.02 & 0.04 & 0.04 & 0.04 \\
\hline Carbon dioxide & $\mathrm{mg} / \mathrm{l}$ & & & 6.67 & 5.05 & 13.11 & 11.37 & 8.82 & 6.48 \\
\hline Copper & $\mathrm{mg} / \mathrm{l}$ & 1 & $0.02-1.0$ & 0.02 & 0.02 & 0.02 & 0.02 & 0.02 & 0.02 \\
\hline Chloride & $\mathrm{mg} / \mathrm{l}$ & 250 & $25-250$ & 19 & 6 & 20 & 6 & 19 & 5 \\
\hline Cyanide & $\mathrm{mg} / \mathrm{l}$ & 0.07 & $0.07-1.0$ & 0.001 & 0.002 & 0.001 & 0.002 & 0.001 & 0.002 \\
\hline Chromium total & $\mathrm{mg} / \mathrm{l}$ & & 0.05 & 0.014 & 0.016 & 0.012 & 0.007 & 0.011 & 0.006 \\
\hline Chromium hexa & $\mathrm{mg} / \mathrm{l}$ & 0.05 & 0.05 & 0.006 & 0.007 & 0.005 & 0.006 & 0.006 & 0.007 \\
\hline Fluoride & $\mathrm{mg} / \mathrm{l}$ & 1.5 & $0.1-1.5$ & 0.13 & 0.09 & 0.15 & 0.10 & 0.15 & 0.11 \\
\hline Iron & $\mathrm{mg} / \mathrm{l}$ & 0.3 & $1.0-0.3$ & 0.01 & 0.01 & 0.03 & 0.02 & 0.03 & 0.02 \\
\hline Manganese & $\mathrm{mg} / \mathrm{l}$ & 0.1 & $0.05-0.5$ & 0.010 & 0.024 & 0.011 & 0.015 & 0.015 & 0.018 \\
\hline Nitrate nitrogen & $\mathrm{mg} / \mathrm{l}$ & & & 1.13 & 0.58 & 1.51 & 0.45 & 1.29 & 0.42 \\
\hline Nitrate & $\mathrm{mg} / \mathrm{l}$ & 50 & $5.0-50$ & 4.9 & 2.5 & 6.7 & 2.0 & 5.7 & 1.9 \\
\hline Nitrite nitrogen & $\mathrm{mg} / \mathrm{l}$ & & & 0.004 & 0.002 & 0.004 & 0.001 & 0.003 & 0.001 \\
\hline Nitrite & $\mathrm{mg} / \mathrm{l}$ & 3 & $1.0-3.0$ & 0.011 & 0.005 & 0.011 & 0.004 & 0.011 & 0.004 \\
\hline Zinc & $\mathrm{mg} / \mathrm{l}$ & 3 & $0.5-3.0$ & 0.036 & 0.034 & 0.026 & 0.021 & 0.032 & 0.038 \\
\hline Phosphate & $\mathrm{mg} / \mathrm{l}$ & & & 0.055 & 0.057 & 0.097 & 0.096 & 0.088 & 0.086 \\
\hline Sulphide & $\mathrm{mg} / \mathrm{l}$ & 0.05 & 0 & 0.002 & 0.003 & 0.002 & 0.003 & 0.003 & 0.003 \\
\hline Sulphate & $\mathrm{mg} / \mathrm{l}$ & 250 & $25-250$ & 17 & 5 & 17 & 4 & 18 & 6 \\
\hline \multicolumn{10}{|l|}{ Biological test } \\
\hline Freely available chlorine & $\mathrm{mg} / \mathrm{l}$ & $0.2-0.5$ & $0.1-1$ & 0.8 & 0.1 & 0.8 & 0.1 & 0.8 & 0.1 \\
\hline Total AC & $\mathrm{mg} / \mathrm{l}$ & & 2 & 0.9 & 0.1 & 1.0 & 0.1 & 0.9 & 0.1 \\
\hline Total coliform & $\mathrm{cfu} / 100 \mathrm{ml}$ & 0 & 0 & 0 & 0.0 & 0 & 0.0 & 0 & 0.0 \\
\hline Faecal coliform & $\mathrm{cfu} / 100 \mathrm{ml}$ & 0 & 0 & 0 & 0.0 & 0 & 0.0 & 0 & 0.0 \\
\hline
\end{tabular}

\section{Discussion}

Phnom Penh, the capital city of Cambodia, uses water resources from the Mekong River as well as the Tonle Sap and Tonle Bassac rivers. At Phnom Penh, the Mekong has four arms, known as the "Quatre-Bras", where the Tonle Sap river, the Bassac River and the inflowing and outflowing branches of the Mekong river join. These three rivers form an unusual ' $X$ ' shaped layout (see Fig. 1), which follows a very unusual flow regime during the year. 


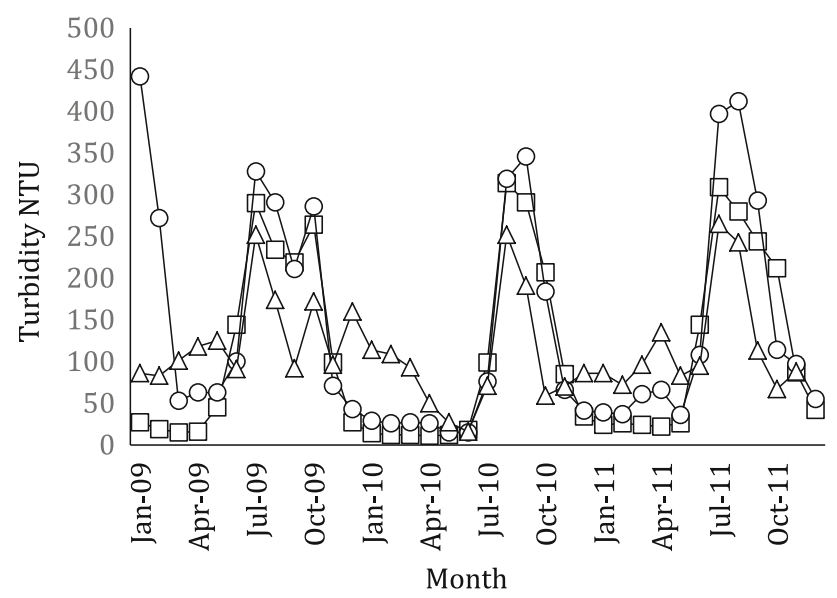

Fig. 2 Average monthly turbidity measured for the source waters at the Chruoy Changvar (squares), Chamkar Mon (circles) and Phum Prek (triangles) WTP's from 2009 to 2011

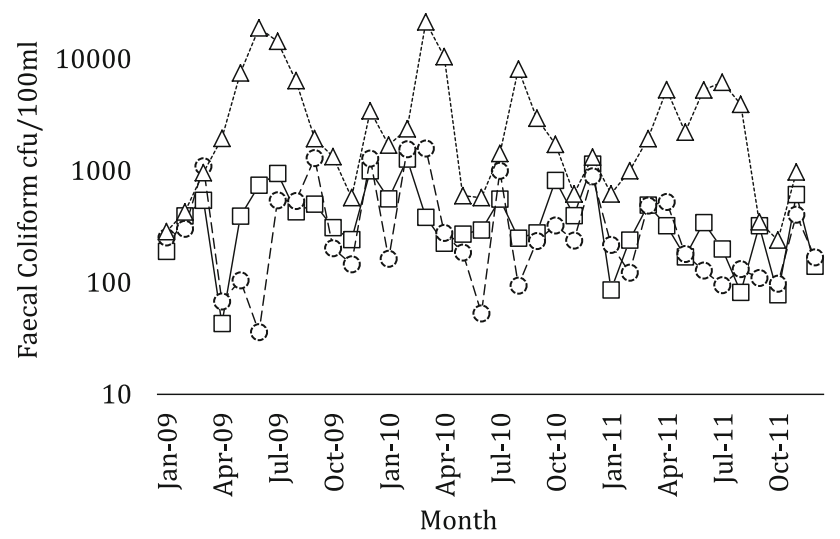

Fig. 3 Average monthly faecal coliform counts (log scale) for the source waters at the Chruoy Changvar (squares), Chamkar Mon (circles) and Phum Prek (triangles) WTP's from 2009 to 2011

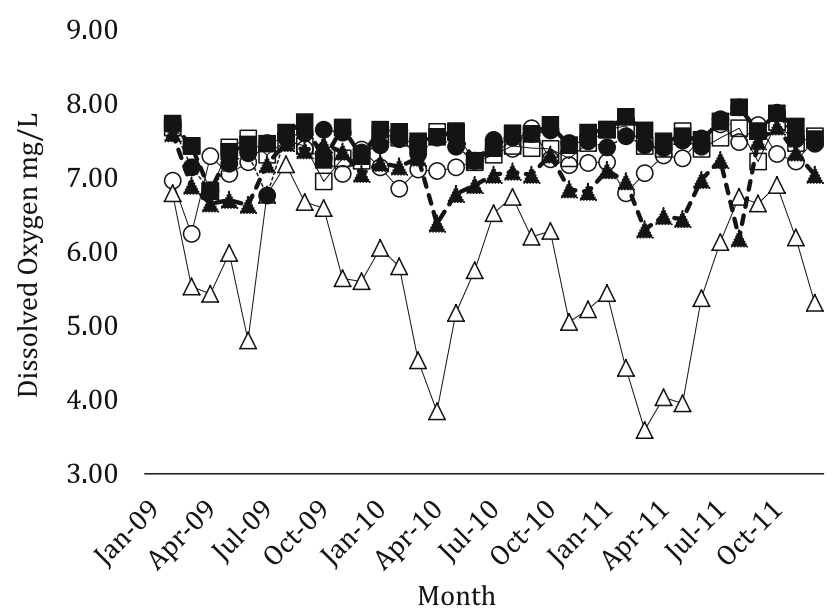

Fig. 4 Average monthly dissolved oxygen concentration measured at the Chruoy Changvar (squares), Chamkar Mon (circles) and Phum Prek (triangles) WTP's from 2009 to 2011. Open symbols are for the source water and filled symbols are for treated water
The flow of the Mekong River during the dry season depends heavily on the Tonle Sap Lake located about $100 \mathrm{~km}$ to the northwest of the city. The lake stores water during the wet season and releases it during the dry season, acting as an important natural hydrological buffer (May et al. 2011; Sarkkula et al. 2005; Yen et al. 2007). The Tonle Sap River between Phnom Penh and the lake reverses its flow twice a year, first filling and then draining the lake. During the months of June to December, the monsoonal flooding of the Mekong causes the flow direction of the Tonle Sap to be from Phnom Penh up into the lake, and for the remainder of the year, the lake empties through the Tonle Sap river which meets the Mekong and Bassac rivers at Phnom Penh. These surface waters are affected by the seasonal conditions, and during the wet season, they regularly inundate the flood plains surrounding the rivers and their tributaries. The Tonle Sap Lake is subject to resuspension of particulate matter and contamination with chemical discharges from industry and from pesticides and fertilizers from agriculture, particularly during the wet season (Matsui et al. 2006; Yen et al. 2007).

On the basis of the data presented above, the following observations can be made. Firstly, the quality of the Mekong, Bassac and Tonle Sap river water is adequate as source water and can be rendered suitable for drinking with only basic water treatment, with concerns that the high coliform counts indicate the presence of pathogens that may not be rendered inert by treatment. The primary requirements are disinfection, which is readily achieved with the addition of chlorine and clarification. Clarification is achieved by flocculating the suspended material with the addition of aluminum sulphate. Secondly, for all the parameters measured, the treated water quality exceeds the requirements set out by the WHO and the CNDWQS, and the expansion of the capacity and the network for water delivery has seen a dramatic increase in water availability to consumers over recent decades. Thirdly, the quality of the water treated in the plant is in the vast majority of cases delivered at the tap. However, to be confident in these observations, further analysis or investigation is required. The issues that need to be addressed are enumerated below.

1. Statistical relevance of the mean: the standard deviations for many of the measurements are high and this means that the mean values reported do not in themselves necessarily provide an adequate measure.

2. Validity of the results: as a general test of the quality of the data, a number of trends were examined, to determine if the results reflect processes that are occurring in the real world. For example, some measures of water quality will be altered by the water treatment processes, whereas others should not be. 
Table 4 Tap water quality measures reported as mean and standard deviation for the year 2011 from measurements made weekly at $\sim 25$ locations around Phnom Penh

\begin{tabular}{|c|c|c|c|c|c|c|c|c|}
\hline & \multirow[t]{2}{*}{$\mathrm{pH}$} & \multirow{2}{*}{$\begin{array}{l}\text { Turbidity } \\
\text { NTU }\end{array}$} & \multirow{2}{*}{$\begin{array}{l}\text { Colour } \\
\mathrm{Pt} / \mathrm{co}\end{array}$} & \multirow{2}{*}{$\begin{array}{l}\text { Conductivity } \\
\mu \mathrm{S} / \mathrm{cm}\end{array}$} & \multicolumn{2}{|c|}{ Residual chlorine } & \multirow{2}{*}{$\begin{array}{l}\text { Total coliform } \\
\text { CFU/100 ml }\end{array}$} & \multirow{2}{*}{$\begin{array}{l}\text { E. coli } \\
\text { CFU/100 ml }\end{array}$} \\
\hline & & & & & FAC mg/l & $\mathrm{TAC} \mathrm{mg} / \mathrm{l}$ & & \\
\hline WHO (2004) & $6.5-8.5$ & 5 & 15 & 400 & $0.1-1.0$ & 2 & 0 & 0 \\
\hline Mean & 7.21 & 1.36 & 3.69 & 130.13 & 0.31 & 0.41 & $0.19^{\mathrm{a}}$ & 0.00 \\
\hline$\pm \mathrm{STD}$ & 0.22 & 0.72 & 2.05 & 27.17 & 0.12 & 0.12 & $\mathrm{~N} / \mathrm{A}^{\mathrm{a}}$ & 0 \\
\hline $\operatorname{Max}$ & 8.07 & 9.37 & 16.19 & 207 & 1.04 & 1.2 & 92 & 0 \\
\hline
\end{tabular}

${ }^{a}$ Only two non-zero values were recorded, where contamination arose from the distribution pipe

3. Applicability of results: the WHO drinking water standards cover many more measures of water quality than those tested here. Knowledge of the water quality, as measured by these other parameters, is required before the water can be declared safe for drinking.

4. Are the results relevant? For the consumer, the ultimate measure is not the quality of the water after treatment but the quality of the water delivered at the tap. Does the sampling method at the tap reflect the quality of the water being delivered to the consumer?

\section{Statistical relevance of the mean}

The primary concern in setting the drinking water standards is to ensure that exposure to harmful agents at concentrations in which they may adversely affect health is avoided. Health effects can be both acute and chronic. Chronic effects arise due to long-term exposure to harmful agents; this is particularly relevant to species that accumulate in the body such as lead and arsenic. In such cases, the average exposure over a long period is a good measure of how this agent might influence health. As the data summarised above are based on daily measurements averaged over 3 years, the mean is a very suitable measure for agents that accumulate and result in chronic health effects. Acute effects arise due to short-term exposures. Typically, the exposure level that can be tolerated for short periods is very much higher than the level that is dangerous over long periods, but this is not always the case. For example, high levels of nitrite in water when fed to young infants can lead to methaemoglobinaemia (Finan et al. 1998), also known as "blue baby" syndrome. The provisional WHO guidelines for nitrite for acute exposure to infants are $3 \mathrm{mg} / \mathrm{l}$, whereas the long-term exposure value is $0.2 \mathrm{mg} / \mathrm{l}$ (WHO 2004). Therefore, it is important that not only the mean value, but also the peak values of nitrite are considered when assessing water quality. The maximum values measured at the 3 water treatment plants in the period 2009-2011 (see Table 5) are tabulated below. Only values for aluminum and sulphide exceeded the WHO guidelines in the period of investigation. The high aluminum value is probably a result of overdosing of aluminum sulphate, which is used as a flocculent, and is unlikely to pose any health risk. High values of aluminum can increase the turbidity and adversely influence the flavour of water and therefore will impact on the consumer. The sulphide concentration in the drinking water does not present a health risk, but it will be present as hydrogen sulphide, which results in an offensive odour, commonly known as 'rotten egg gas'. This will cause consumer dissatisfaction. In Table 4, which is the assessment of tap water quality, the maximum values measured over the year have been included. Four values have exceeded the standard. The biggest concern is the coliform count which registered a non-zero value on two occasions out of a total of $>1000$ measurements. These could indicate the presence of pathogens at dangerous levels. The turbidity and colour maximums are above the level of the standard and would contribute to negative perceptions of water quality, but do not alone indicate a health risk. This is also the case for the slightly elevated residual chlorine level, which likely arose from overdosing, due to operator error. It is clear that even when the maximal values for the parameters measured over a 3-year period are compared against the WHO standard, the quality of the treated water from the three WTP's can be considered to be very good. Similarly, the tap water quality indicators are good, based on the samples measured, though the sampling is currently inadequate as discussed below.

\section{Validity of the results}

The measured water quality parameters are investigated below, to determine if they are consistent with the realworld physical-chemical processes occurring in the treatment plant. Water quality measures before and after treatment at the three PPWSA treatment plants are compared in Table 6 . The water quality measures that are 
Table 5 Treated water from the three treatment plants of PPWSA maximum recorded values for quality measures in the period 2009-2011

\begin{tabular}{|c|c|c|c|c|c|}
\hline Item & Unit & $\begin{array}{l}\text { Standard } \\
\text { WHO }\end{array}$ & $\begin{array}{l}\text { CCW-WTP } \\
\text { Maximum }\end{array}$ & $\begin{array}{l}\text { PP-WTP } \\
\text { Maximum }\end{array}$ & $\begin{array}{l}\text { CCM-WTP } \\
\text { Maximum }\end{array}$ \\
\hline \multicolumn{6}{|l|}{ Physical test } \\
\hline Temperature & ${ }^{\circ} \mathrm{C}$ & & 30.7 & 30.1 & 30.8 \\
\hline $\mathrm{pH}$ & & $6.5-8.5$ & 7.82 & 7.23 & 7.21 \\
\hline Turbidity & NTU & 5 & 1.21 & 1.04 & 2.57 \\
\hline Conductivity & $\mu \mathrm{S} / \mathrm{cm}$ & 400 & 192 & 174 & 190 \\
\hline Colour & TCU & 15 & 3.27 & 3.86 & 4.92 \\
\hline SS & $\mathrm{mg} / \mathrm{l}$ & 1 & 0.27 & 0.45 & 1 \\
\hline TDS & $\mathrm{mg} / \mathrm{l}$ & 1000 & 96 & 87 & 95 \\
\hline \multicolumn{6}{|l|}{ Chemical test } \\
\hline $\mathrm{Ca}$ hardness & $\mathrm{mg} / \mathrm{l}$ & 70 & 55 & 50 & 47 \\
\hline Total hardness & $\mathrm{mg} / \mathrm{l}$ & 100 & 79 & 66 & 60 \\
\hline Magnesium hardness & $\mathrm{mg} / \mathrm{l}$ & 30 & 24 & 18 & 21 \\
\hline Alkalinity & $\mathrm{mg} / \mathrm{l}$ & 350 & 70 & 45 & 45 \\
\hline Organic substance & $\mathrm{mg} / \mathrm{l}$ & & 4.78 & 7.64 & 5.8 \\
\hline Dissolved oxygen & $\mathrm{mg} / \mathrm{l}$ & & 7.95 & 7.69 & 7.95 \\
\hline UV, absorption & & & 0.036 & 0.076 & 0.057 \\
\hline Aluminum & $\mathrm{mg} / \mathrm{l}$ & $0.05-0.2$ & 0.304 & 0.11 & 0.089 \\
\hline Ammonia & $\mathrm{mg} / \mathrm{l}$ & & 0.1 & 0.1 & 0.086 \\
\hline Ammonia nitrogen & $\mathrm{mg} / \mathrm{l}$ & $0.05-0.5$ & 0.12 & 0.08 & 0.07 \\
\hline Carbon dioxide & $\mathrm{mg} / \mathrm{l}$ & & 23 & 29 & 18 \\
\hline Copper & $\mathrm{mg} / \mathrm{l}$ & $0.02-1.0$ & 0.08 & 0.05 & 0.006 \\
\hline Chloride & $\mathrm{mg} / \mathrm{l}$ & $25-250$ & 24.5 & 40 & 24 \\
\hline Cyanide & $\mathrm{mg} / \mathrm{l}$ & $0.07-1.0$ & 0.005 & 0.05 & 0.006 \\
\hline Chromium total & $\mathrm{mg} / \mathrm{l}$ & 0.05 & 0.02 & 0.02 & 0.02 \\
\hline Chromium hexa & $\mathrm{mg} / \mathrm{l}$ & 0.05 & 0.02 & 0.02 & 0.02 \\
\hline Fluoride & $\mathrm{mg} / \mathrm{l}$ & $0.1-1.5$ & 0.37 & 0.36 & 0.42 \\
\hline Iron & $\mathrm{mg} / \mathrm{l}$ & $1.0-0.3$ & 0.06 & 0.09 & 0.05 \\
\hline Manganese & $\mathrm{mg} / \mathrm{l}$ & $0.05-0.5$ & 0.045 & 0.04 & 0.045 \\
\hline Nitrate nitrogen & $\mathrm{mg} / \mathrm{l}$ & & 2.1 & 2.4 & 2.3 \\
\hline Nitrate & $\mathrm{mg} / \mathrm{l}$ & $5.0-50$ & 9.28 & 10.61 & 10.16 \\
\hline Nitrite nitrogen & $\mathrm{mg} / \mathrm{l}$ & & 0.006 & 0.004 & 0.005 \\
\hline Nitrite & $\mathrm{mg} / \mathrm{l}$ & $1.0-3.0$ & 0.02 & 0.013 & 0.017 \\
\hline Zinc & $\mathrm{mg} / \mathrm{l}$ & $0.5-3.0$ & 0.07 & 0.06 & 0.12 \\
\hline Phosphate & $\mathrm{mg} / \mathrm{l}$ & & 0.16 & 0.37 & 0.19 \\
\hline Sulphide & $\mathrm{mg} / \mathrm{l}$ & 0 & 0.003 & 0.002 & 0.004 \\
\hline Sulphate & $\mathrm{mg} / \mathrm{l}$ & $25-250$ & 19 & 23 & 26 \\
\hline \multicolumn{6}{|l|}{ Biological test } \\
\hline FAC & $\mathrm{mg} / \mathrm{l}$ & $0.1-1$ & 0.78 & 0.81 & 0.8 \\
\hline TAC & $\mathrm{mg} / \mathrm{l}$ & 2 & 0.9 & 0.95 & 0.92 \\
\hline Total coliform & $\mathrm{cfu} / 100 \mathrm{ml}$ & 0 & 0 & 0 & 0 \\
\hline Faecal coliform & $\mathrm{cfu} / 100 \mathrm{ml}$ & 0 & 0 & 0 & 0 \\
\hline
\end{tabular}

improved substantially by water treatment were turbidity, colour, suspended solids, ammonia, nitrite and iron. The flocculation process is expected to improve the turbidity, colour and suspended solids but not the measures for iron, nitrite and ammonia. Iron is mostly present as ferrous iron, $\mathrm{Fe}^{2+}$, which is highly soluble. However, it can be oxidised to the ferric iron, $\mathrm{Fe}^{3+}$, form, which is only sparingly soluble. This is achieved in the water treatment plant by the addition of chlorine, which creates hypochlorous acid. Hypochlorous acid is a strong oxidising agent and will readily oxidise iron to the insoluble form, which is then filtered out. Thus, the large drop in the iron concentration 
Table 6 Comparison of measures of water quality before and after treatment

\begin{tabular}{|c|c|c|c|c|c|}
\hline Item & Unit & $\mathrm{PP}(\%)$ & $\mathrm{CCW}(\%)$ & WTP $(\%)$ & Overall mean $(\%)$ \\
\hline \multicolumn{6}{|l|}{ Physical test } \\
\hline Temperature & ${ }^{\circ} \mathrm{C}$ & 99.1 & 99.1 & 99.6 & 99.3 \\
\hline $\mathrm{pH}$ & & 96.2 & 95.1 & 94.5 & 95.3 \\
\hline Turbidity & NTU & 0.8 & 0.7 & 1.3 & 0.9 \\
\hline Conductivity & $\mu \mathrm{S} / \mathrm{cm}$ & 114.6 & 102.7 & 106.9 & 108.1 \\
\hline Colour & TCU & 6.5 & 7.2 & 3.6 & 5.8 \\
\hline SS & $\mathrm{mg} / \mathrm{l}$ & 0.3 & 0.1 & 1.6 & 0.7 \\
\hline TDS & $\mathrm{mg} / \mathrm{l}$ & 114.0 & 102.8 & 108.6 & 108.5 \\
\hline \multicolumn{6}{|l|}{ Chemical test } \\
\hline Ca hardness & $\mathrm{mg} / \mathrm{l}$ & 119.6 & 98.2 & 100.0 & 105.9 \\
\hline Total hardness & $\mathrm{mg} / \mathrm{l}$ & 114.2 & 98.8 & 100.0 & 104.3 \\
\hline Magnesium hardness & $\mathrm{mg} / \mathrm{l}$ & 102.1 & 100.4 & 101.4 & 101.3 \\
\hline Alkalinity & $\mathrm{mg} / \mathrm{l}$ & 79.0 & 86.1 & 79.5 & 81.5 \\
\hline Organic substance & $\mathrm{mg} / \mathrm{l}$ & 27.3 & 30.5 & 30.2 & 29.3 \\
\hline Dissolved oxygen & $\mathrm{mg} / \mathrm{l}$ & 123.4 & 101.6 & 103.0 & 109.4 \\
\hline UV, absorption & & 19.2 & 20.0 & 21.7 & 20.3 \\
\hline Aluminum & $\mathrm{mg} / \mathrm{l}$ & - & 266.7 & 500.0 & 383.3 \\
\hline Ammonia & $\mathrm{mg} / \mathrm{l}$ & 6.7 & 23.1 & 19.4 & 16.4 \\
\hline Ammonia nitrogen & $\mathrm{mg} / \mathrm{l}$ & 5.3 & 27.3 & 23.5 & 18.7 \\
\hline Carbon dioxide & $\mathrm{mg} / \mathrm{l}$ & 91.1 & 121.1 & 110.3 & 107.5 \\
\hline Copper & $\mathrm{mg} / \mathrm{l}$ & 100.0 & 100.0 & 100.0 & 100.0 \\
\hline Chloride & $\mathrm{mg} / \mathrm{l}$ & 117.0 & 106.3 & 113.1 & 112.1 \\
\hline Cyanide & $\mathrm{mg} / \mathrm{l}$ & - & - & - & - \\
\hline Chromium total & $\mathrm{mg} / \mathrm{l}$ & 120.0 & 140.0 & 110.0 & 123.3 \\
\hline Chromium hexa & $\mathrm{mg} / \mathrm{l}$ & 50.0 & 60.0 & 60.0 & 56.7 \\
\hline Fluoride & $\mathrm{mg} / \mathrm{l}$ & 115.4 & 92.9 & 125.0 & 111.1 \\
\hline Iron & $\mathrm{mg} / \mathrm{l}$ & 6.7 & 7.7 & 10.0 & 8.1 \\
\hline Manganese & $\mathrm{mg} / \mathrm{l}$ & 55.0 & 50.0 & 78.9 & 61.3 \\
\hline Nitrate nitrogen & $\mathrm{mg} / \mathrm{l}$ & 93.8 & 93.4 & 102.4 & 96.5 \\
\hline Nitrate & $\mathrm{mg} / \mathrm{l}$ & 105.3 & 91.9 & 102.7 & 100.0 \\
\hline Nitrite nitrogen & $\mathrm{mg} / \mathrm{l}$ & 40.0 & 40.0 & 33.3 & 37.8 \\
\hline Nitrite & $\mathrm{mg} / \mathrm{l}$ & 32.4 & 55.0 & 39.3 & 42.2 \\
\hline Zinc & $\mathrm{mg} / \mathrm{l}$ & 52.0 & 60.0 & 80.0 & 64.0 \\
\hline Phosphate & $\mathrm{mg} / \mathrm{l}$ & 64.7 & 68.8 & 67.7 & 67.0 \\
\hline Sulphide & $\mathrm{mg} / \mathrm{l}$ & 20.0 & 20.0 & 33.3 & 24.4 \\
\hline Sulphate & $\mathrm{mg} / \mathrm{l}$ & 354.2 & 149.8 & 285.7 & 263.2 \\
\hline
\end{tabular}

seen in the data is what would be expected from the treatment processes and will also contribute to the reduction in colour. Similarly, hypochlorous acid will oxidise nitrite to nitrate, which explains the drop in nitrite levels. Ammonia is a base and it is converted by acid to the ammonium ion. The chlorination process produces hypochlorous and hydrochloric acids so it is expected that the level of ammonia will be reduced in agreement with the measurements.

Parameters that increased substantially following water treatment were aluminum, chromium, fluoride and sulphate. The salt, aluminum sulphate, is added in the water treatment process so the increase in concentration of $\mathrm{Al}_{3}{ }^{+}$ and $\mathrm{SO}_{4}^{2-}$ ions is expected. Fluoride is not intentionally added to the water, so the increase seen is at first surprising. However, both fluoride and chromium are present in very low concentrations both before and after testing and as such the small increases seen after treatment are not statistically significant. We can conclude from the above analysis that the changes seen in the water quality measures due to water treatment are entirely consistent with those expected from the physical and chemical processes that occur. This lends confidence to the measurement and reporting of the water quality measures. 


\section{Applicability of the results}

The WHO release guidelines on concentration limits for a vast number of chemicals (WHO 2004), yet only a fraction of these are tested as part of the water quality assurance programme in Phnom Penh. Those notably absent are tests for arsenic, lead and pesticides. Arsenic is known to be present in the groundwater in Cambodia and has led to widespread contamination of ground water drinking sources (Bennett et al. 2010; Buschmann et al. 2008; Feldman et al. 2007; Hashim et al. 2013; Sampson et al. 2008), with serious health implications for those using the water. The full extent of the impact on health may not be revealed for some years due to the slow onset of symptoms of arsenic poisoning (Buschmann et al. 2008; Hashim et al. 2013). Lead is a heavy metal that accumulates in the body, leading to chronic disease including mental development retardation, particularly in children (Grandjean and Landrigan 2006). There is concern about pesticide use amongst the population of Phnom Penh that has spurned a demand for organically grown fruit vegetables (Wang et al. 2011). The use of pesticides is poorly regulated, and pesticides that are banned in other countries are known to find their way into Cambodia (Kunisue et al. 2004; Specht 1996). Therefore, one might be concerned about its presence in the water supply in Phnom Penh. A WHO-sponsored study of these chemicals in water supplies across Cambodia included samples from the Mekong and Tonle Sap rivers. This study, in which samples were processed in a certified lab in Australia, found that levels of the arsenic and lead in the rivers were at low and safe levels (Feldman et al. 2007). Furthermore, two categories of pesticides were investigated, organochlorines and organophosphates, and found to be undetectable by gas chromatography or mass spectrometry (Feldman et al. 2007). Therefore, on current evidence, the source water for the Phnom Penh water supply is free of these contaminants and there is little reason to test for them on a daily basis; however, as the demands on these rivers change, it would be wise to periodically check for the presence of these and other contaminants. The consistently high coliform counts in the source water may be indicative of other pathogens such as viruses and coliphage. It is recommended that steps be taken to prevent the contamination of the source waters at Phum Prek with output from the nearby sewerage treatment works. No tests have been conducted to ascertain the levels of these pathogens and as such their levels in the source and treated waters are currently unknown.

\section{Are the results relevant?}

The main measures of water quality are performed on samples taken immediately after treatment in the plant.
Following treatment, the water is stored and then distributed through pipes to consumers. To protect against bacterial contamination occurring after treatment, a residual dose of chlorine is applied. The PPWSA does testing of tap water on a weekly basis from $>20$ sites around $\mathrm{Ph}-$ nom Penh. The parameters measured that are most relevant to public health are the coliform counts and the measures of freely available chlorine (FAC) and total available chlorine (TAC). It is not desirable to have FAC and TAC levels near zero, rather the values reported of a few tenths of a milligram per litre are ideal to provide for residual bacterial protection (WHO 2004). On two occasions, non-zero coliform counts were detected during the year, and these were traced back to the distribution pipe. So this testing regime at first appears to be sufficient and to demonstrate that the tap water supplied is of high quality. However, some criticisms can be made of the protocols employed. In order to reduce costs, employees at the plant collect their own tap water once per week and these are the samples that are analysed. This has two implications. Firstly, the number of taps sampled across the year is very small $(<30)$, and the distribution of the sampling is not randomised but determined by the residential address of the workers. So there could easily be parts of the city in which the tap water is never tested. Additionally, when performing coliform testing, once the sample has been acquired, it should be refrigerated immediately. It is unlikely that this protocol was followed, as employees do not have the means to refrigerate samples during their commute. Noting that the weather is tropical in Phnom Penh, this may influence the measurements. In order to properly ascertain representative measures of tap water quality, the sampling process should be completely overhauled. A process whereby samples are taken from all areas of the city should be devised, and a vehicle equipped with appropriate refrigerated storage should be used to collect and transport the samples for testing. The extra costs could be partially recouped by offering tap water testing to some consumers on a commercial basis. That is customers could opt to pay to have their tap water tested either on an ad hoc or regular basis. It has been reported that Phnom Penh water consumers are very concerned about water quality and are willing to pay more for water of higher quality (Dany et al. 2000). The implication is that some of the population would also pay to have the tap water in their residence tested. If this could be performed on a commercial basis, the receipts could be used to offset the costs of testing across the distribution network.

\section{Future threats to water quality}

The main threat to the ability of PPWSA to deliver quality water in the future is degradation in the quality of the 
source water. As the water treatment plants operate using basic flocculation and disinfection technology, they are not suited to the removal of nutrients, heavy metals, viruses or pesticides. The technologies required for the removal of these species (ion exchange, biological treatment, activated carbon filtering, UV and ozonolysis) are currently not installed and would take some time and significant cost to implement. Furthermore, they would add considerably to the ongoing cost of water treatment. Therefore, any significant presence of these contaminants in the river water would be passed on to the consumer. It is therefore essential that the quality of the river water is monitored and protected. As a necessary step, ongoing monitoring of the water quality in the rivers needs to be conducted and expanded to include periodic testing of heavy metals and pesticides. Furthermore, testing for coliphages and viruses would provide information on the levels of these pathogens, which the coliform counts indicate may be high. These threats are substantial and real as Phnom Penh is a rapidly growing city with increasing industrialization. Also the Mekong basin is experiencing strong population growth, development and more intensive farming practices (Baran and Jantunen 2005; Liljeström et al. 2012; Navy and Bhattarai 2009). More intensive upstream agricultural activities threaten to increase the nitrate levels (Baran and Jantunen 2005; Herbst et al. 2009; Navy and Bhattarai 2009; Udomchoke et al. 2010; Yen et al. 2007) in the source waters. Currently, the water treatment plants have no capacity to reduce nitrate levels so any increase in nitrate in the supply water will be passed onto consumers. The river systems supplying the source water are also experiencing a host of other changes that threaten the water quality (Campbell 2005; Rajendran 2003; Serrat 2005; Udomchoke et al. 2010; Yen et al. 2007) from climate change (Wingqvist 2009) to dam construction (Baird 2011). The protection of the source water quality is politically challenging as there are significant economic pressures promoting development as well as conflicting regional interests (Chomchai 1997; Dapice and Xuan 2012; Ojendal et al. 2012; Wong and Lewis 2013).

\section{Conclusions}

The quality of the source water, treated water and water delivered to the tap for the Phnom Penh municipal water supply has been assessed. Based on the water parameters being measured, the municipal supply of water in Phnom Penh is of good quality. This is despite only basic water treatment processes being employed. The implication is that the water quality is sufficient, primarily because the source water from the Mekong, Bassac and Tonle Sap rivers is of good quality. Therefore, for long-term safeguarding of the water quality, the source water catchments need to be safeguarded. This is a significant environmental and political challenge. In the immediate future, the testing of tap water needs to expanded and reorganised. This process could be aided by offering tap water testing to households as an additional commercial service. This would have the benefit of increasing the level of testing at the point of delivery without introducing additional costs.

Acknowledgments The authors thank M. Bodman for assistance with the English language in this manuscript and the reviewers for their careful reading of the manuscript and very helpful and erudite comments. Sokly Siev is thanked for his assistance with the preparation of Fig. 1.

\section{References}

Baird IG (2011) The Don Sahong Dam. Crit Asian Stud 43:211-235. doi:10.1080/14672715.2011.570567

Baran E, Jantunen TA (2005) BayFish-Tonle Sap: a Bayesian model of the fish production in the tonle Sap Great Lake, Cambodia. In: Zerger A, Argent RM (eds) MODSIM 2005 international congress on modelling and simulation. Modelling and simulation society of Australia and New Zealand, pp 170-176

Bennett HB, Shantz A, Shin G, Sampson ML, Meschke JS (2010) Characterisation of the water quality from open and rope-pump shallow wells in rural Cambodia. Water Sci Technol 61:473-479. doi:10.2166/wst.2010.817

Biswas AK, Tortajada C (2010) Water supply of Phnom Penh: an example of good governance. Int $\mathbf{J}$ Water Resour Dev 26:157-172. doi:10.1080/07900621003768859

Buschmann J, Berg M, Stengel C, Winkel L, Sampson ML, Trang PTK, Viet PH (2008) Contamination of drinking water resources in the Mekong delta floodplains: arsenic and other trace metals pose serious health risks to population. Environ Int 34:756-764. doi:10.1016/j.envint.2007.12.025

Cambodia MoimaeKo (2004) Drinking water quality standards. http:// rdic.org/wp-content/uploads/2014/12/MIME-Drinking-WaterQuality-Standards-2004-en.pdf

Campbell I (2005) Managing health of large rivers in developing regions : a case study from the Mekong. In: Proceedings of the 2nd international Yellow River forum on keeping healthy life of the river, 1st edn, vol 2. Yellow River Conservancy Press, Beijing

Chomchai P (1997) Transboundary environmental issues in the Mekong basin. International boundaries and environmental security frameworks for regional cooperation. Kluwer Law International, The Hague

Couillard D, Lefebvre Y (1985) Analysis of water-quality indexes. J Environ Manage 21:161-179

Dany V, Visvanatha C, Thanh NC (2000) Evaluation of water supply systems in Phnom Penh city: a review of the present status and future prospects. Int J Water Resour Dev 16:677-689

Dapice D, Xuan VT (2012) The Mekong delta: rural development meets the environment-systemic challenges and possible solutions. J Macromarketing 32:147-151. doi:10.1177/0276146711 426433

Feldman PR, Rosenboom J-W, Saray M, Navuth P, Samnang C, Iddings S (2007) Assessment of the chemical quality of drinking water in Cambodia. J Water Health 5(1):101-116

Finan A, Keenan P, O’Donovan F, Mayne P, Murphy J (1998) Lesson of the week-methaemoglobinaemia associated with sodium nitrite in three siblings. Br Med J 317:1138-1139 
Grandjean P, Landrigan PJ (2006) Developmental neurotoxicity of industrial chemicals. Lancet 368:2167-2178. doi:10.1016/s01406736(06)69665-7

Hallock D (2002) A water quality index for ecology's stream monitoring program. Washington State Department of Ecology, Olympia

Hashim JH et al (2013) Hair arsenic levels and prevalence of arsenicosis in three Cambodian provinces. Sci Total Environ 463:1210-1216. doi:10.1016/j.scitotenv.2013.04.084

Herbst S, Benedikter S, Koester U, Phan N, Berger C, Rechenburg A, Kistemann T (2009) Perceptions of water, sanitation and health: a case study from the Mekong Delta, Vietnam. Water Sci Tech 60:699-707. doi:10.2166/wst.2009.442

Kunisue T, Someya M, Monirith I, Watanabe M, Tana TS, Tanabe S (2004) Occurrence of PCBs, organochlorine insecticides, tris(4chlorophenyl)methane, and tris(4-chlorophenyl)methanol in human breast milk collected from Cambodia. Arch Environ Contam Toxicol 46:405-412. doi:10.1007/s00244-003-3008-7

Liljeström I, Kummu M, Varis O (2012) Nutrient Balance Assessment in the Mekong Basin: nitrogen and phosphorus dynamics in a catchment scale. Int J Water Resour Dev 28:373-391. doi:10. 1080/07900627.2012.668649

Matsui S, Keskinen M, Sokhem P, Nakamura M (2006) Tonle Sap: experience and lessons learned brief. International Waters: Science Database. http://projects.csg.uwaterloo.ca/inweh. Accessed Mar 2014

May R, Jinno K, Tsutsumi A (2011) Influence of flooding on groundwater flow in central Cambodia. Environ Earth Sci 63:151-161. doi:10.1007/s12665-010-0679-z

Mitchell MK, Stapp WB (2000) Field manual for water quality monitoring: environmental education program for schools, 12th edn. Kendall Hunt Publishing, Dubuque

Navy H, Bhattarai M (2009) Economics and livelihoods of smallscale inland fisheries in the Lower Mekong Basin: a survey of three communities in Cambodia. Water Policy 11:31-51. doi:10. 2166/wp.2009.002

Ojendal J, Hansson S, Hellberg S (eds) (2012) Politics and development in a transboundary watershed: the case of the Lower Mekong Basin. Springer, Dordrecht. doi:10.1007/978-94007-0476-3

PPWSA (2014) Drinking water quality standards. http://rdic.org/wpcontent/uploads/2014/12/MIME-Drinking-Water-Quality-Stan dards-2004-en.pdf

Rajendran CR (2003) Future solutions now. Asian Development Bank, Manilla
Sampson ML, Bostick B, Chiew H, Hagan JM, Shantz A (2008) Arsenicosis in Cambodia: case studies and policy response. Appl Geochem 23:2977-2986. doi:10.1016/j.apgeochem.2008.06.022

Sarkkula J, Koponen J, Kummu M (2005) Tools for integrated Basin Flow management at lower Mekong Basin Floodplains. Modsim 2005: International congress on modelling and simulation: advances and applications for management and decision making: advances and applications for management and decision making

Serrat O (2005) Threats to the Tonle Sap. Asian Development Bank

Sobsey MD (2006) Drinking water and health research: a look to the future in the United States and globally. J Water Health 04(suppl):17-21. doi:10.2166/wh.2005.035

Specht J (1996) Pesticides in Cambodia. Report Prepared for Lutheran World Service, Phnom Penh

Thailand MMoNRaEo (2006) Cambodian National EPA report

Udomchoke V et al (2010) The ecological complexity of the ThaiLaos Mekong River: I geology, seasonal variation and human impact assessment on river quality. J Env Scie Health Part A Toxic Haz Subst Env Eng 45:1661-1673. doi:10.1080/ 10934529.2010 .513207

Un K (2005) Patronage politics and hybrid democracy: political change in Cambodia, 1993-2003. Asian Perspect 29:203-230

UNICEF (2006) State of the World's children report 2006. UNICEF, New York

UNICEF (2014a) Basic statistics by country. http://www.unicef.org/ infobycountry/cambodia_statistics.html-113

UNICEF (2014b) State of the World's children report 2014. UNICEF, New York

Wang HS et al (2011) Daily intake and human risk assessment of organochlorine pesticides (OCPs) based on Cambodian market basket data. J Haz Mater 192:1441-1449. doi:10.1016/j.jhazmat. 2011.06.062

WHO (2004) Guidelines for drinking-water quality, vol 1. World Health Organisation, Geneva

Wingqvist GÖ (2009) Cambodia environmental and climate change policy brief. Gothenburg

Wong YL, Lewis L (2013) The disappearing environmental kuznets Curve: a study of water quality in the Lower Mekong Basin (LMB). J Environ Manage 131:415-425. doi:10.1016/j.jenvman. 2013.10.002

Yen NTH, Sunda K, Oishi S, Ikejima K (2007) Tonle Sap ecosystem water quality index development and fish production. In: Kungolos A, Brebbia CA, Beriatos E (eds) Sustainable development and Planning III, vol 2. Wit transactions on ecology and the environment, pp 901-912. doi:10.2495/sdp070862 